\title{
Box model analysis of bacterial fluxes in the St. Lawrence Estuary
}

\author{
Jean Painchaud, Denis Lefaivre, Jean-Claude Therriault
}

Institut Maurice-Lamontagne, Ministère des Pêches et des Océans, CP 1000, Mont-Joli, Québec G5H 3Z4, Canada

\begin{abstract}
To interpret the distribution of bacteria in the St. Lawrence Estuary, Canada, and in an attempt to identify the processes controlling it, bacterial abundance, heterotrophic activity, chlorophyll $a$, temperature and salinity data were examined. Bacterial data in particular were analyzed using a 2-dimensional box model. Horizontal and vertical bacterial fluxes were calculated for each box and net rates, indicative of production and loss of bacteria, were estimated. The model was characterized by large negative fluxes downstream of the salinity intrusion which, in combination with experimental and microscopical evidence, suggests that freshwater bacteria entrained in brackish waters died massively. Calculations and field measurements showed that the growth of bacteria entrained upstream in the deep layer of the estuary could be sufficient to make up for the loss of the freshwater bacteria and maintain the observed distribution. The results suggest that the limit of salinity intrusion is a sharp ecological barrier between 2 distinct bacterial communities: the freshwater community on one side and the estuarine community on the other side. Loss terms observed further downstream were possibly due to intense grazing by flagellates, themselves preyed upon by the large copepod populations existing in the same area. The hypotheses generated by the field data and the flux calculations are summarized in a conceptual model.
\end{abstract}

\section{INTRODUCTION}

Ketchum (1954) pointed out that the observed distribution of an estuarine population can be correctly interpreted only when both the circulation and the biological processes controlling the abundance of this population are taken into account. Thus, the pattern of bacterial distribution in estuaries must be examined as the result of the interaction between physical dispersion vs growth, mortality and predation processes. Although few measurements are available, bacterial production and growth seem significant in estuaries (e.g. Ducklow 1982, Albright 1983b, Christian et al. 1984), and suggest that bacteria are not simply passive drifters. Predation has also been observed on estuarine bacteria (Haas \& Webb 1979, Davis \& Sieburth 1984, Wright \& Coffin 1984). However, estimating the rates of these biological processes is difficult: it requires incubation of numerous water samples from many stations, which is expensive in terms of manpower, ship-time and materials. Moreover, it is rarely possible to collect these samples synoptically. Thus, the spatial and temporal variations of growth, predation and mortality of estuarine bacteria have not yet been properly charac- terized. Physical dispersion, on the other hand, is controlled by the usually complex hydrodynamics of the estuary, but it can be estimated from simple hydrographic, topographic and freshwater flow data fed into an empirical flushing model of the type developed by Pritchard (1969).

Up to now, only one study took into account these different processes, to elucidate the fate of coliform bacteria in the Raritan River (New Jersey, USA) (Ketchum et al. 1952). No other similar study has ever been undertaken on natural bacteria, with the result that a general model of estuarine bacterial dynamics is badly missing to microbial ecologists. As a consequence, the numerous studies dealing with bacterial distribution in estuaries have mostly produced descriptive information. Generally, a gradient of decreasing bacterial numbers with increasing salinity has been observed, which has occasionally been interpreted as indicative of conservative behavior (Palumbo \& Ferguson 1978). Such a frequent pattern suggests that there must be some similarity in the mechanisms controlling bacterial abundance in different estuaries. However, other patterns have also been reported recently, such as peaks of bacteria in the mid-region of estuaries 
(Wright \& Coffin 1983, Palumbo et al. 1984), or minimum abundance in mid-estuarine regions (Prieur et al. 1984), or gradient of increasing bacterial numbers with increasing salinity (Christian et al. 1984). The physical and biological processes underlying these distribution patterns have generally been overlooked.

The aim of the present paper is to examine bacterial abundance, heterotrophic activity, chlorophyll $a$, temperature and salinity data collected during the summer of 1982 in the St. Lawrence Estuary, in an attempt to generate plausible hypotheses on the processes controlling bacterial distribution in estuaries. A set of bacterial abundance data was analyzed using a 2-dimensional box model (Officer 1980). The estuary was divided into 10 segments between which exchange coefficients were calculated from the observed values of salinity, using the salt continuity equation. The other inputs required for flux calculation were the freshwater flow and the mean bacterial abundance per segment. The net fluxes per box indicated sources and sinks of bacteria which were interpreted in terms of growth, mortality and predation. These were compared to available information of in situ and experimental rates of bacterial growth and mortality, and with presence and abundance of potential predators. The hypotheses generated by the present study are summarized in a conceptual model of bacterial dynamics in an estuarine environment.

\section{MATERIALS AND METHODS}

Sampling was carried out at 9 stations in the St. Lawrence Estuary, Canada, from 31 Jul to 6 Aug 1982 (Fig. 1). At each station, temperature and salinity profiles were measured using a Guildline model 8705 CTD probe. Bacteria were sampled using a cast of 6 Niskin bottles lowered at depths corresponding to 100,30 and
$1 \%$ of the surface incident radiation (using Secchi disk measurements) and, under the photic zone, at 3 equidistant depths down to a few meters above the bottom.

From each Niskin bottle, a $10 \mathrm{ml}$ subsample was preserved with glutaraldehyde at a final concentration of $1 \%$. Subsequent counting of the bacteria was carried out with a Leitz epifluorescence microscope following staining of the cells with Acridine Orange and filtration on $25 \mathrm{~mm}, 0.2 \mu \mathrm{m}$ Nuclepore filters (Hobbie et al. 1977).

The physiological state of the bacteria was estimated from their specific heterotrophic activity (Wright 1978). The maximum rate of uptake $\left(\mathrm{V}_{\max }\right)$ of L-glutamic acid [L- $\left({ }^{14} \mathrm{C}(\mathrm{U})\right]$; New England Nuclear, specific activity: 250 to $300 \mathrm{mCi} \mathrm{mmol}^{-1}$ ] was measured using a technique similar to that of Griffiths et al. (1977), whereby only one substrate concentration showing full uptake saturation was utilised. Values of $\mathrm{V}_{\max }$ measured this way were equivalent to those resulting from the more material-and time-consuming technique of Wright \& Hobbie (1966). Care was taken to check regularly that substrate uptake was linear with time and that substrate concentration was saturating. Radioactivity of the samples was measured using a Rack Beta LKB Wallac liquid scintillation counter, model 1215-005. The channel ratio method was used to determine counting efficiency. $V_{\max }$ values were divided by bacterial numbers to obtain specific heterotrophic activity.

To estimate the magnitude of bacterial growth in the upper estuary, thymidine incorporation was measured in fresh and in low salinity (0 to $10 \%$ ) water in September 1983. The procedure was essentially that of Fuhrman \& Azam $(1980,1982)$. Samples of $10 \mathrm{ml}$ were placed in Whirl-Pack bags and were inoculated with $15 \mu$ [ [methyl- ${ }^{3} \mathrm{H}$ ]-thymidine (New England Nuclear; specific activity: 70 to $\left.80 \mathrm{Ci} \mathrm{mmol}^{-1}\right)$. Incubations were carried out at in situ temperature $\left( \pm 2^{\circ} \mathrm{C}\right)$. After $20 \mathrm{~min}$, the bags were placed in an ice bath and $10 \mathrm{ml}$ of ice-

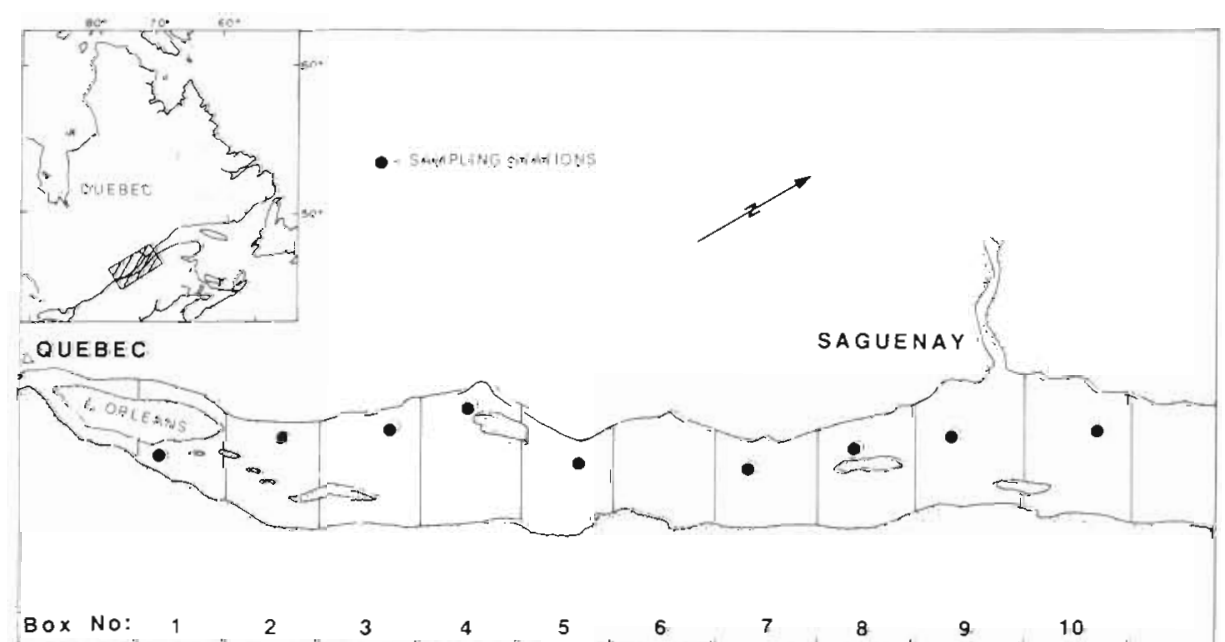

Fig. 1. Map of the St. Lawrence Estuary showing station locations and box model boundaries 
cold $10 \%$ trichloroacetic acid (TCA) was added to each sample. After $5 \mathrm{~min}$, the samples were filtered on 0.45 um Gelman Metricel GN-6 filters. Filtering funnels and filters were rinsed several times with $5 \%$ TCA. The filters were then placed in glass scintillation vials and $1 \mathrm{ml}$ of ethyl acetate was added. After $10 \mathrm{~min}, 10 \mathrm{ml}$ Aquasol were added. Scintillation counting was carried out as above.

Transforming thymidine incorporation values into bacterial production rates requires the introduction of a conversion factor, which was derived from data on the growth (monitored by cell counts) and thymidine uptake of freshwater and estuarine bacteria in $0.45 \mu \mathrm{m}$ filtered water (Fuhrman \& Azam 1982). We grew different cultures consisting of 0,5 and $10 \%$ water inoculated with natural bacteria previously filtered through a $1 \mu \mathrm{m}$ Nuclepore filter to exclude predators. The results are shown on Fig. 2 along with the regression equation

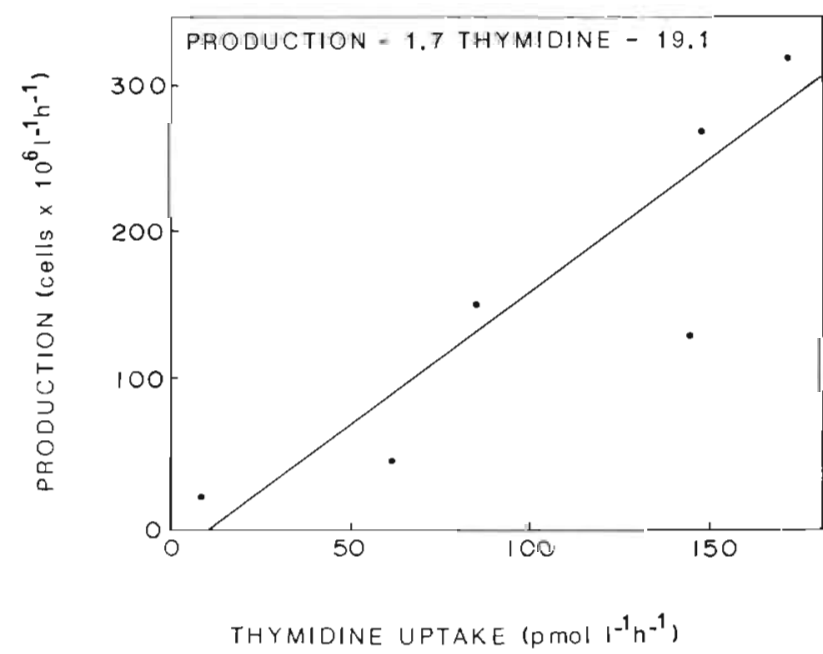

Fig. 2. Relation between thymidine uptake and cell production measured in 0,5 and $10 \%$ dilution cultures

used to transform thymidine incorporation into bacterial production rate.

To examine experimentally the fate of freshwater bacteria entrained into low salinity waters, freshwater was enclosed in $600 \mathrm{ml}$ diffusion chambers which were immersed in $10 \mathrm{l}$ estuarine water of salinity $5 \%$. The chambers were similar to those used by Valdés \& Albright (1981). They were closed at each end by $0.2 \mu \mathrm{m}$ pore-size Nuclepore membranes of $142 \mathrm{~mm}$ diameter. Two chambers were used simultaneously: one control and one experimental that were immersed in fresh and estuarine water respectively. Salinity within the experimental chamber equilibrated with outside salinity within $24 \mathrm{~h}$. Thymidine incorporation was monitored simultaneously in the 2 chambers.
Flux calculation. The distribution of any dissolved or particulate component in the estuarine environment is partially (or totally, in the case of a conservative component) controlled by the circulation. In either a partially mixed or in a stratified estuary, the circulation pattern is characterized by a net seaward flow in the surface layer and a net landward flow in the deeper layer. There is also a net vertical motion directed from the deeper to the surface layer. Flux calculation allows one to determine if the distribution of the component is solely controlled by this circulation or if other processes are involved. It also allows one to calculate the rate of production or loss and to identify regions of source and sink of the component. These calculations are significant only if the circulation, hence the salinity and the bacterial distributions, is in steady state. The St. Lawrence Estuary is broad and long, its circulation is mainly driven by a large and relatively steady freshwater discharge (ca $10000 \mathrm{~m}^{3} \mathrm{~s}^{-1}$, reaching ca 15000 $\mathrm{m}^{3} \mathrm{~s}^{-1}$ in April-May; Pocklington \& Tan 1983). The water column being stratified due to the important freshwater outflow, and the estuarine circulation being well developed, wind events do not significantly control transport. Therefore, distributions based on salinity and bacterial data averaged over one tidal cycle represent steady-state distributions and can be used to calculate transport in the St. Lawrence Estuary.

The theory underlying the calculation of the fluxes can be outlined as follows. First, a circulation model for the estuary was determined. Stratification being appreciable in the study area (see 'Results'), a 2-dimensional model was needed. A box model requiring no prior information on advection and on diffusion coefficients was used. The study area was segmented longitudinally and vertically; advective and non-advective exchange coefficients between the segments were determined from the observed tidally-averaged values of salinity within each segment and the continuity equation. The product of the exchange coefficients with the river discharge yielded the horizontal and vertical fluxes of water $\left(\mathrm{m}^{3} \mathrm{~s}^{-1}\right)$ in and out of each box. Bacterial fluxes (cells s ${ }^{-1}$ ) were obtained from the product of the tidally-averaged bacterial abundance (cells $\mathrm{m}^{-3}$ ) with the water fluxes. The summation of all fluxes for a given box yielded the net flux. For a conservative constituent, the net flux is zero, whereas any positive or negative net flux indicates respectively production or loss of a bio- or geochemically active variable. However, flux values have no volume dimensions since they are given for the segment as a whole. Because the segments are unequal in size, flux values must be divided by the volume of each box to get rates of production or loss expressed as cells volume $e^{-1}$ time $e^{-1}$. These values can then be compared to in situ measurements. 
Following is a summary of specific steps in the calculation of fluxes. The study area was segmented longitudinally into 10 equidistant boxes of length $10 \mathrm{n}$ mile. Box 1 consisted of freshwater and was considered well mixed; its seaward boundary was set at the average position of the salinity intrusion. All following boxes had vertical density gradients and thus were vertically divided with horizontal boundaries set at the average position of the pycnocline. Computation of exchange coefficients followed the methodology of Officer (1980). The exchange coefficients between Boxes 1. (mixed) and 2 (stratified) were calculated using Officer's equations 101 to 104, which apply to mixed 1 and 2-dimensional box models. Calculation of exchange coefficients between Boxes 2 to 10 followed Officer's equations for 2-dimensional box models (Eqs. 10 and 80 to 86 ). However, the nature of longitudinal dispersion is not uniform throughout our study area. In the deeper portion of the estuary, the salt balance is controlled entirely by advection, whereas with decreasing depths and increasing friction in the upper region of the estuary, the salt flux is increasingly controlled by diffusion through tidal exchange. The equations used to calculate exchange coefficients took diffusion into account through the use of the variable $v$, the diffusive fraction. A value of 0.2 was set for Boxes 2 to 5 and a value of 0 for Boxes 6 to 10. A verification of the model was done by comparing net water fluxes to residual current measurements obtained by Meric (1975) in Boxes 2 to 4 under similar river discharge conditions (Table 1). Agreement between computed and field values was satisfactory.

Table 1 Comparison of calculated and observed residual current values $\left(\mathrm{m} \mathrm{s}^{-1}\right)$ in Boxes 2 to 4

\begin{tabular}{|ccrc|}
\hline \multirow{2}{*}{ Box } & Layer & Model & Meric (1975) \\
\hline \multirow{2}{*}{3} & Upper & 0.20 & 0.28 \\
& Lower & -0.02 & 0.08 \\
& Upper & 0.15 & 0.18 \\
\multirow{3}{*}{4} & Lower & -0.06 & -0.06 \\
& Upper & 0.17 & 0.14 \\
& Lower & -0.09 & -0.02 \\
\hline
\end{tabular}

\section{RESULTS}

Fig. 3 shows the longitudinal and vertical distribution of salinity, temperature, chlorophyll $a$, bacterial abundance and specific heterotrophic activity in the St. Lawrence Estuary, in July-August 1982. Surface salinity ranged from 0 in Box 1 to values higher than $20 \%$ in Boxes 8 to 10 . In the deeper part of the estuary, salinity was greater than 30\%. Surface tempera- ture exceeded $20^{\circ} \mathrm{C}$ in Box 1 and decreased to around $10^{\circ} \mathrm{C}$ in Box 10 ; temperature values less than $5^{\circ} \mathrm{C}$ were found in the deeper layer of the last 5 boxes. Temperature and salinity isolines show that stratification, already evident in Box 2, increased markedly seaward. Neu (1970) has pointed out that moderately stratified conditions prevail in the study area. El-Sabh (1979) attempted to characterize further the St. Lawrence Estuary by using Hansen \& Rattray's (1966) stratification-circulation diagram and concluded that all the upper St. Lawrence Estuary falls in Hansen \& Rattray's estuarine type $2 \mathrm{~b}$, where the stratification is considered appreciable. These results indicate that from Boxes 2 to 10, a 2-layered estuarine circulation prevails, necessitating the use of a 2-dimensional model to investigate the dispersion of a component.

Chlorophyll a was higher than $5 \mu \mathrm{g} \mathrm{l}^{-1}$ in freshwater, but decreased rapidly to values less than $1 \mu \mathrm{g} \mathrm{l^{-1 }}$ in the mid-estuarine region before rising again in surface water at the seaward end of the estuary to values greater than $3 \mu \mathrm{g} \mathrm{l}^{-1}$. Bacterial abundance decreased gradually from over $3 \times 10^{6}$ cells $\mathrm{ml}^{-1}$ in freshwater to values one order of magnitude lower in the surface waters of the last 3 boxes. Significant vertical gradients were also observed. Specific heterotrophic activity showed a very different pattern. It was high at the head of the estuary, but decreased rapidly from Box 1 to 3 and varied little thereafter, with most values around $0.10 \pm 0.02 \mathrm{pg}$ glu cell ${ }^{-1} \mathrm{~h}^{-1}$. This physiological uniformity of estuarine bacteria suggests that they form a homogeneous community, different from that found in freshwater. Thus, although bacterial abundance decreases monotonously from fresh to estuarine waters, an important qualitative difference may take place at low salinity. Information on bacterial size and morphology gathered at 5 stations throughout the study area (Table 2) supports this suggestion. In Box 1 (freshwater), the bacteria were mostly spherical cells categorized here as 'cocci' $(81 \%)$, the rest being cylindrical cells or 'rods'. At estuarine stations, the proportion of cocci was lower, ranging from 49 to $65 \%$, while the proportion of rods increased to between 34 and $46 \%$ of the total. Comma-like cells (1 to $11 \%$ of

Table 2. Percentage and average size (um) of cocci, rods and vibrios at 5 stations in the St. Lawrence Estuary

\begin{tabular}{|rccc|}
\hline Box & Cocci & Rods & Vibrios \\
\hline 1 & $81(0.38)$ & $19(0.73 \times 0.36)$ & 0 \\
3 & $65(0.47)$ & $34(1.01 \times 0.41)$ & $1(1.72 \times 0.52)$ \\
5 & $49(0.49)$ & $46(1.16 \times 0.50)$ & $5(2.10 \times 0.46)$ \\
9 & $49(0.55)$ & $40(1.10 \times 0.47)$ & $11(2.02 \times 0.47)$ \\
10 & $64(0.52)$ & $35(1.01 \times 0.49)$ & $1(1.03 \times 0.34)$ \\
\hline
\end{tabular}




\section{BOX NUMBER}

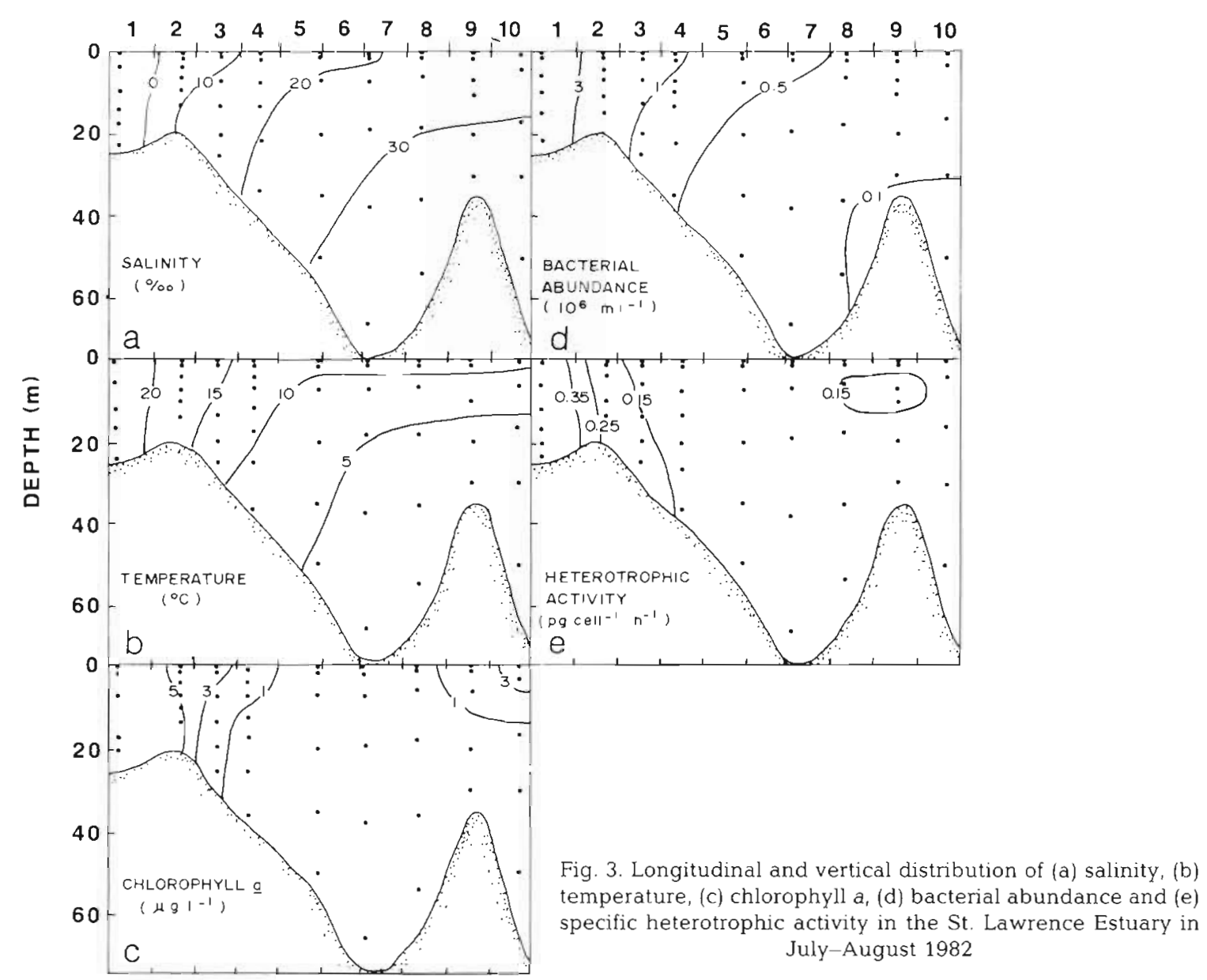

the total), that we labelled 'vibrios', were always present in estuarine water and absent in freshwater. Another qualitative difference between freshwater cells and their estuarine counterpart was their average size. Freshwater cells were smaller: the average freshwater cocci were $0.38 \mu \mathrm{m}$ in diameter compared to $0.50 \mathrm{um}$ for estuarine cocci. Similarly, freshwater rods had mean linear dimensions of $0.73 \times 0.36 \mu \mathrm{m}$, whereas estuarine cells were $1.0 \times 0.45 \mu \mathrm{m}$.

Results of bacterial flux calculation are presented in Fig. 4. For each box, horizontal and vertical fluxes are presented with arrows corresponding to the direction of the flux (Fig. 4a). As expected, downstream horizontal fluxes were observed in the surface layer and upstream fluxes at depth. Vertical fluxes were upwards except for the last 2 boxes. The summation of all fluxes in a given box yields the net flux, shown in Fig. 4a with a plus or minus sign. The surface layer was characterized by net negative fluxes, whereas the opposite was observed in most of the deep layer. Note that the absence of volume dimen- sions can be misleading: upper Boxes 3 and 7 seemed to lose bacteria at the same rate, but the loss per unit volume was more important in Box 3 due to its smaller size. Correcting the net fluxes by the volume of their respective box yielded rates of production or loss per liter per hour (Fig. 4b). The largest rates were in the upstream region of the estuary and indicated important removal of bacteria in this area. The highest loss rate of all the estuary was found in the deep layer of Box 2. Since the main input of bacteria into surface and deep layer of this box originated from freshwater, our results suggest that the freshwater cells might suffer heavy mortality due to increasing salinity. Upper Box 3 and 4 also show important bacterial loss rates, which suggests that processes removing bacteria dominated there too. Downstream of Box 4, the rates of loss in the surface layer were smaller, particularly in Boxes 5 and 6 , where they neared zero; the rates increased again in the last 3 boxes, particularly in Box 7 . All rates in the deeper layer downstream of Box 2 were low and most 
a

BOX NUMBER
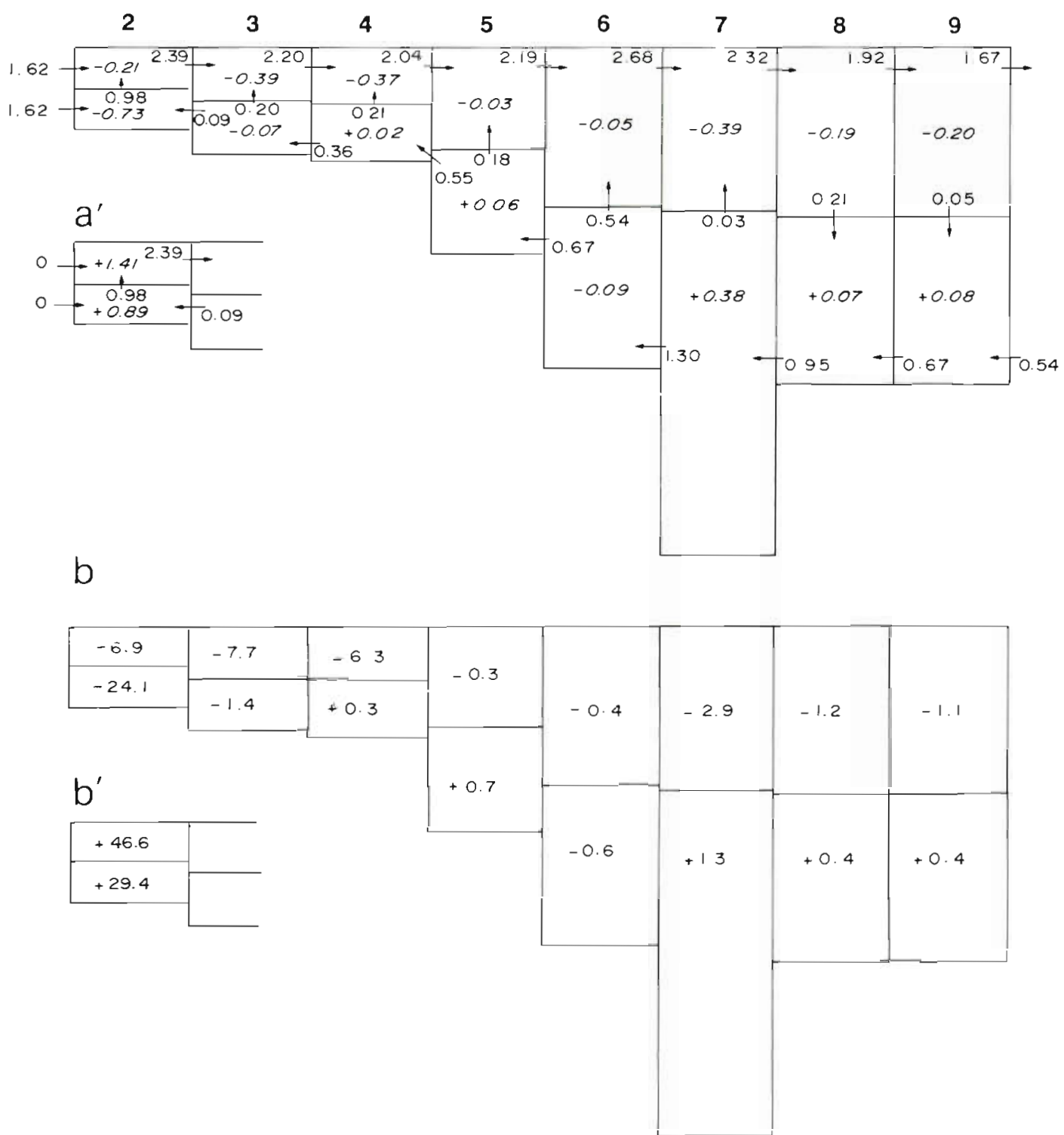

Fig. 4. (a) Box model showing bacterial fluxes $\left(10^{16}\right.$ cells s$\left.^{-1}\right)$ in the St. Lawrence Estuary. Net fluxes with plus and minus sign are shown in the middle of each box. (b) Rates of production and loss $\left(10^{6}\right.$ cells $\left.\mathrm{l}^{-1} \mathrm{~h}^{-1}\right)$ of each box. (a') Recalculated fluxes in Box 2 assuming null fluxes from freshwater $\left(b^{\prime}\right)$ Recalculated production and loss terms in Box 2

of them were near zero. This suggests that no biological process drastically altered bacterial abundance in deeper waters of the St. Lawrence and that the most important processes took place near the head of the estuary.

To document further the behavior of bacteria in this sensitive stretch of the estuary, we estimated bacterial production in September 1983, in waters of salinity ranging from 0 to $10 \%$ which correspond to Boxes 2 and 3 (Table 3). The results showed that bacterial production was important in this region, with most values larger than $20 \times 10^{6}$ cells $\mathrm{l}^{-1} \mathrm{~h}^{-1}$.
This is in apparent contradiction to the calculated rates of loss, which ranged from 7 to $24 \times 10^{6}{\text { cells } 1^{-1}}^{-1}$ $h^{-1}$. We also examined the fate of freshwater bacteria with diffusion chambers. Our experiments showed that thymidine incorporation in a chamber filled with freshwater decreased rapidly after immersion in water of salinity of $5 \%$ and remained low thereafter, whereas a control chamber, immersed in freshwater, had linearly increasing thymidine uptake (Fig. 5). This observation indicates that the growth of freshwater bacteria is impeded by exposure to brackish waters. 
Table 3. Thymidine uptake and bacterial production at the head of St. Lawrence Estuary, September 1983

\begin{tabular}{|cccc|}
\hline Date & Salinity & $\begin{array}{c}\text { Thymidine uptake } \\
\left(\mathrm{pmol} \mathrm{l}^{-1} \mathrm{~h}^{-1}\right)\end{array}$ & $\begin{array}{c}\text { Production } \\
\left.\text { (cells } \times 10^{6} \mathrm{l}^{-1} \mathrm{~h}^{-1}\right)\end{array}$ \\
\hline 1 Sep & 0 & 43.2 & 54.3 \\
& 2.3 & 27.2 & 27.1 \\
& 5.1 & 19.7 & 14.4 \\
13 Sep & 7.8 & 16.2 & 8.4 \\
& 0 & 53.1 & 71.2 \\
& 0 & 34.2 & 39.0 \\
& 1.0 & 41.4 & 51.3 \\
& 2.9 & 44.7 & 56.9 \\
& 5.0 & 31.5 & 34.5 \\
& 7.7 & 29.0 & 30.3 \\
9.4 & 24.2 & 22.2 \\
Sep & 0 & 39.0 & 47.2 \\
& 0.1 & 32.7 & 36.5 \\
0.8 & 36.3 & 42.6 \\
4.8 & 33.9 & 38.5 \\
7.2 & 38.1 & 45.7 \\
10.3 & 22.7 & 19.5 \\
\hline
\end{tabular}

\section{DISCUSSION}

\section{Distribution pattern}

Our survey revealed that bacterial numbers decreased gradually with distance downstream. Similar distribution patterns have been reported frequently (Table 4). It is noteworthy that such gradients are observed even among estuaries with different physical properties (length, topography, river discharge, stratification-circulation ratio) and probably wide differences in ecological characteristics. For example, estuaries such as those of the Newport River (North Carolina, USA) and North Inlet (South Carolina, USA) are small, shallow and surrounded by extensive tidal flats; they diverge drastically from long, deep estuaries like those of the Hudson (New York, USA), Fraser (British Columbia, Canada) and St. Lawrence rivers. Yet, the resemblance of their bacterial distribution patterns suggests a certain similarity in the processes affecting estuarine bacteria. Thus, it must be possible to find unifying principles and to develop a comprehensive model of bacterial dynamics applicable to most estuaries. The first step in the interpretation of estuarine bacterial distribution is the identification of the processes contributing most to controlling bacterial numbers. When the important processes are identified, they must be quantified and included in a proper circulation model. Considerations in choosing a model are summarized by Fischer et al. (1979), particularly with regard to the choice between 1 and 2-dimensional models. When well-

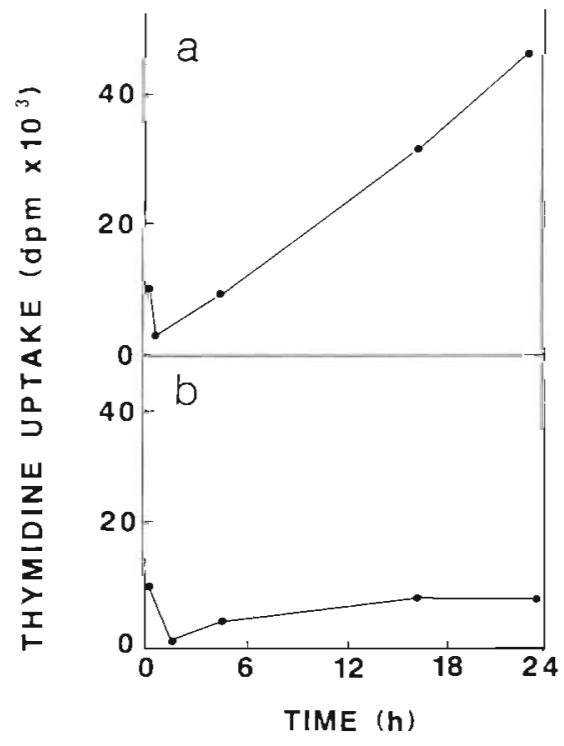

Fig. 5. Thymidine incorporation of freshwater bacteria contained within diffusion chambers. (a) Control: chamber immersed in freshwater; (b) experimental: chamber immersed in water of salinity $5 \%$

Table 4. Recent reports of estuarine studies showing gradients of decreasing bacterial abundance with increasing salinity

\begin{tabular}{|c|c|}
\hline Estuary & Source \\
\hline $\begin{array}{l}\text { Chesapeake Bay } \\
\text { subestuary, USA }\end{array}$ & Erkenbrecher 1982 \\
\hline Elbe River, FR Germany & Rheinheimer 1979 \\
\hline $\begin{array}{l}\text { Essex \& Merrimack Rivers, } \\
\text { MA, USA }\end{array}$ & Wright, 1978 \\
\hline Fraser River, BC, Canada & $\begin{array}{l}\text { Bell \& Albright 1981, Al- } \\
\text { bright 1983a \& b }\end{array}$ \\
\hline $\begin{array}{l}\text { Gironde River, France } \\
\text { (winter) }\end{array}$ & Prieur et al. 1984 \\
\hline Hudson Plume, NY, USA & Ducklow \& Kirchman 1983 \\
\hline $\begin{array}{l}\text { Kiel Bight and Fjord, } \\
\text { FR Germany }\end{array}$ & Zimmermann 1977 \\
\hline Newport River, NC, USA & Palumbo \& Ferguson 1978 \\
\hline $\begin{array}{l}\text { North Inlet Marsh, SC, } \\
\text { USA }\end{array}$ & Wilson et al. 1981 \\
\hline $\begin{array}{l}\text { Severn River-Bristol } \\
\text { Channel, UK }\end{array}$ & Joint \& Pomeroy 1982 \\
\hline
\end{tabular}

mixed conditions prevail or when only rough approximations are sought, 1-dimensional models are satisfactory. However, to interpret properly the dispersion of any component in a stratified estuary, 2-dimensional models are required. At any rate, simple examination of either the distribution or of the dilution plot (bacterial numbers vs salinity) is insufficient to yield a clear picture of the dynamics of estuarine bacteria. 
However, patterns at variance with that mentioned above have also been reported (Wright \& Coffin 1983, Christian et al. 1984, Palumbo et al. 1984); in the Gironde estuary (France), different distributions have been noted in summer and in winter (Prieur et al. 1984). These observations suggest the existence of a certain variability in the balance between physical and biological processes in the control of bacterial abundance. For instance, the intensity of biological processes and the magnitude of river discharge vary seasonally in temperate estuaries, which is likely to produce different bacterial distribution over an annual cycle. Moreover, the nature of the circulation causes differences among estuaries: dispersion in well-mixed estuaries with small freshwater inputs may be controlled by diffusion through tidal mixing whereas estuarine advection is usually dominant in stratified estuaries. The distribution of bacteria is likely to reflect these different hydrodynamics. Hence, any general model of estuarine bacterial dynamics must take these sources of variation into account.

The exact cause of the usually greater abundance of bacteria in freshwater is not clear. In the St. Lawrence, greater chlorophyll concentrations were also found in freshwater and it is well known that a strong correlation exists between bacterial numbers and chlorophyll concentration in lake and marine waters (Bird \& Kalff 1984). However, various sources contribute to the total organic carbon pool of the St. Lawrence River: landderived organic matter, living and dead organic matter of planktonic origin, and anthropogenic organic matter (Pocklington \& Tan 1983). The extensive tidal flats probably also contribute substrates and bacteria to the estuarine waters: at about the same latitude, an important fraction of the marsh production around Cumberland Basin ( $46^{\circ} \mathrm{N}$, eastern Canada) is thought to be exported from the marshes (Gordon et al. 1985). Finally, water temperature is higher at the head of the estuary and heterotrophic activity is temperaturedependent (Painchaud \& Therriault 1985); therefore growth rates are probably also greater in this area. Thus, several factors contribute to higher bacterial production and abundance in freshwater.

\section{Processes controlling bacterial numbers in the estuary}

The flux calculations presented here allow one to explore field data to identify segments of the estuary where biological processes influence the distribution of the bacteria. If the cells were controlled by physical processes only, all fluxes would be 0 . Any positive or negative value indicates that non-conservative processes superimposed on circulation are at work. Seg- ment 2 in particular, with its important rates of loss, warrants detailed examination. Most bacteria entrained into this box were from freshwater; mortality of these cells, unadapted to life in brackish waters, could account for the observed loss. Our diffusion chamber experiments showed that freshwater bacteria could no longer take up thymidine when exposed to brackish waters. Moreover, in the Fraser River estuary, diffusion experiments similar to those reported here showed that most freshwater bacteria were killed by salinity increases: heterotrophic activities based on glucose uptake were virtually null when the salinity reached approximately $3 \%$ (Valdés \& Albright 1981). If mortality of freshwater bacteria is heavy, most cells downstream of Box 1 must stem from those entrained upstream by the estuarine countercurrent at depth. To test this hypothesis, we examined whether the growth of estuarine cells was sufficient to make up for the loss of the freshwater bacteria and maintain the observed distribution. If we assume that freshwater cells died massively, fluxes from Box 1 into Box 2 must be zero. Recalculating the flux balance within Box 2 yielded positive fluxes in both upper and lower layers of the box (Fig. 4a'). After dividing by the volume of the box and transformation of time units to $\mathrm{h}^{-1}$, the resulting rates of production were 46.6 and $29.4 \times 10^{6}$ cells $^{-1} \mathrm{~h}^{-1}$ in upper and lower Box 2, respectively (Fig. 4b'). By comparison, in situ measurements obtained from thymidine incorporation in samples of salinity 0.1 to $5 \%$ ranged from 27.1 to $56.9 \times 10^{6}$ cells $\mathrm{l}^{-1} \mathrm{~h}^{-1}$ (Table 2 ). Then, the high rates of growth required to maintain the observed distribution, assuming null fluxes from Box 1 into Box 2, become consistent with those measured in situ. The thymidine incorporation method measures gross production whereas our calculations yield net fluxes; consequently, the values obtained by these 2 approaches are not exactly comparable. However, the thymidine estimates do indicate that production is relatively high in Box 2, such as is required by our hypothesis.

Reports from other estuaries also suggest that the segment just below the limit of salinity intrusion might indeed be a region of high bacterial production. In the Tamar Estuary (SW England), Morris et al. (1978) observed a very sharp drop in $\mathrm{O}_{2}$ persistently occurring between salinity 0.1 and $1.0 \%$ and coinciding with chlorophyll fluorescence minimum and dissolved organic carbon peak. They suggested that these observations were indicative of mass mortality of freshwater phytoplankton, leading to plasmolytic release of easily degradable dissolved organic material, which, in turn, supports an active population of $\mathrm{O}_{2}$-utilising bacteria. Similarly, in the James River estuary (Virginia, USA), Filardo \& Dunstan (1985) observed that greater than $50 \%$ of the chlorophyll a biomass measured at $0 \%$ 
disappeared within a narrow range of salinity 10 to $2 \%$ ). Anderson (1986) reported that in coastal plain estuaries of Chesapeake Bay (USA), phytoplankton biomass disappeared rapidly below the limit of salt intrusion, possibly due to lysing of cells in the low salinity region. The release of easily degradable substrates by lysing freshwater organisms could stimulate the growth of estuarine bacteria entrained upstream to the head of the estuary, thus allowing the rapid development of a large estuarine bacterial community just below the limit of salinity intrusion.

There are indications that the passage from fresh to brackish waters strongly changes the composition of the bacterial community. Our results show that specific heterotrophic activity dropped abruptly at the salinity transition, similarly to observations by Wright (1978) in the Merrimack River estuary (Massachusetts, USA). The relative constancy in specific activity below the salt intrusion suggests that all of these halotolerant bacteria have similar metabolic characteristics and therefore form a uniform community, different from that found in freshwater. Moreover, we noticed that freshwater bacteria were smaller than those found at any other station (Table 2); also the relative numerical importance of cocci, rods and vibrios was very different in freshwater with vibrios absent and cocci more abundant than at any other station. In the Cananéia Estuary (Brazil), Watanabe (1980) observed that non-seawater media favored the growth of genera different from those more frequently isolated from media made up with seawater. In the Gironde estuary, Prieur et al. (1984) found that the bacterial community was dominated by halotolerant cells; however, halophobic bacteria present in the freshwater end of the estuary gradually disappeared at low salinity and were replaced by halotolerant bacteria. Fresh-and seawater bacterial communities were characterized by high species diversity, which was lower at intermediate salinities. Similar observations were made in the Elbe estuary (FR Germany) (Rheinheimer 1979) and in the Fraser River estuary (Valdés \& Albright 1981). These observations, coupled to our experimental evidence and our calculations suggest that estuarine waters just below the salt limit might be an ecologically very dynamic zone characterized by opposite processes of large magnitude: growth of estuarine bacteria and mortality of freshwater ones. Thus, on either side of this ecological boundary, different bacterial communities probably exist.

Besides the possible fate of freshwater bacteria, the calculations showed also that below Box 2, the lower layer was largely a source of bacteria except lower Boxes 3 and 6 ; however, the production rates were low. On the contrary, the upper layer of the estuary was essentially a sink for bacteria, particularly upper
Boxes 3 and 4 . This observation is surprising since estuarine waters are usually considered enriched in terms of organic matter derived from riverine inputs and from adjacent wetlands. The surface waters, more influenced by freshwater inputs, should be more enriched than the deeper waters and thus bacteria should show high production rates there. Could the large sink terms observed in upper Boxes 3 and 4 suggest that bacteria continue to experience heavy mortality as they are entrained into saltier waters? The relative uniformity of specific heterotrophic activity values suggests on the contrary that bacteria are not under intense stress in that area. In addition, a diffusion experiment carried out with water of salinity $5 \%$ contained in a chamber immersed in water of salinity $10 \%$ did not show any adverse effect of increasing salinity on thymidine incorporation. Finally, Prieur et al. (1984) observed that the bacterial community of the Gironde estuary is dominated by halotolerant cells, which suggests that estuarine bacteria should be adapted to or selected for salinity variations. Thus, the mortality hypothesis is not very likely.

Alternatively, the balance between production and predation may shift toward a dominance of the latter as bacteria are entrained away from the head of the estuary. Indeed, thymidine incorporation was smaller in samples of salinity 7 to $10 \%$ than in those nearer the freshwater (Table 3). Moreover, ciliates and choanoflagellates showed high numbers in near-surface waters around Box 3 and 4 (Table 5). Choanoflagellates (Lackey 1967, Laval 1971), other flagellates (Haas \& Webb 1979, Fenchel 1982, Davis \& Sieburth 1984) and small ciliates (Sherr et al. 1986) are known bacteriafeeders. There is increasing evidence that predation by flagellates and small ciliates controls the development of bacterial populations (Azam et al. 1983, Andersen \& Fenchel 1985, Rassoulzadegan \& Sheldon 1986). These in turn may be grazed by the copepods. Bousfield et al. (1975) reported that the dominant zooplankton species of the upper St. Lawrence, the copepod Eurytemora affinis, was mostly concentrated in a zone corresponding to Box 3 ; the benthic and epibenthic copepod

Table 5. Abundance of ciliates and choanoflagellates (cells $\left.1^{-1}\right)$ in surface water $(0$ to $7 \mathrm{~m})$ of Boxes 1 to 5

\begin{tabular}{|ccc|}
\hline Box & Ciliates & Choanoflagellates \\
\hline 1 & 8150 & 725 \\
2 & 15400 & 1800 \\
3 & 12233 & 6180 \\
4 & 9166 & 2960 \\
5 & 3666 & 1000 \\
\hline
\end{tabular}


Ectinosoma curticorne also showed high concentrations in this area. It is unlikely that the copepods themselves exert an important grazing pressure on bacteria, but it is possibly significant that the grazing community, from flagellates to copepods, is most developed where the rates of removal of bacteria are the greatest. This suggests that in this area of the estuary, predation may be a major process controlling bacterial abundance.

\section{Conceptual model of bacterial dynamics}

The calculation of bacterial fluxes in the St. Lawrence Estuary has highlighted zones where bacterial numbers are influenced by biological processes that would not have been inferred from simple examination of bacterial distribution or of a dilution plot. Complementary experimental and field data suggested hypotheses regarding the biological processes at work. These are summarized in a conceptual model describing the dynamics of bacteria in the St. Lawrence (Fig. 6). The freshwater Zone I is characterized by high bacterial production due to the presence of abundant substrates and of higher temperature. However, the freshwater bacteria do not survive when entrained into brackish water (Zone II); freshwater phytoplankton and possibly other freshwater organisms also suffer from salinity increases and they release metabolites and cell content. Estuarine bacteria, entrained to the head of the estuary by bottom landward advection and diffusion, grow rapidiy just below the salinity transition (Zone III) due to large amounts of undegraded organics released from freshwater organisms. A rapidly developing estuarine community thus replaces the freshwater community just below the salinity intrusion, which constitutes a sharp ecological barrier separating 2 distinct communities. In the surface layer of the brackish water Zone IV, bacterial growth decreases seaward as the cells move away from the source of labile organics. At depth, production is slightly greater than predation. Important zooplankton and protozoan communities are concentrated near the landward limit of this zone. There, bacteria experience intense grazing. Thus, in estuaries, several biological processes are superimposed on physical dispersion and contribute successively to control bacterial numbers.

The hypotheses generated by the present field and laboratory data and by the flux calculations have been integrated in this conceptual model of bacterial

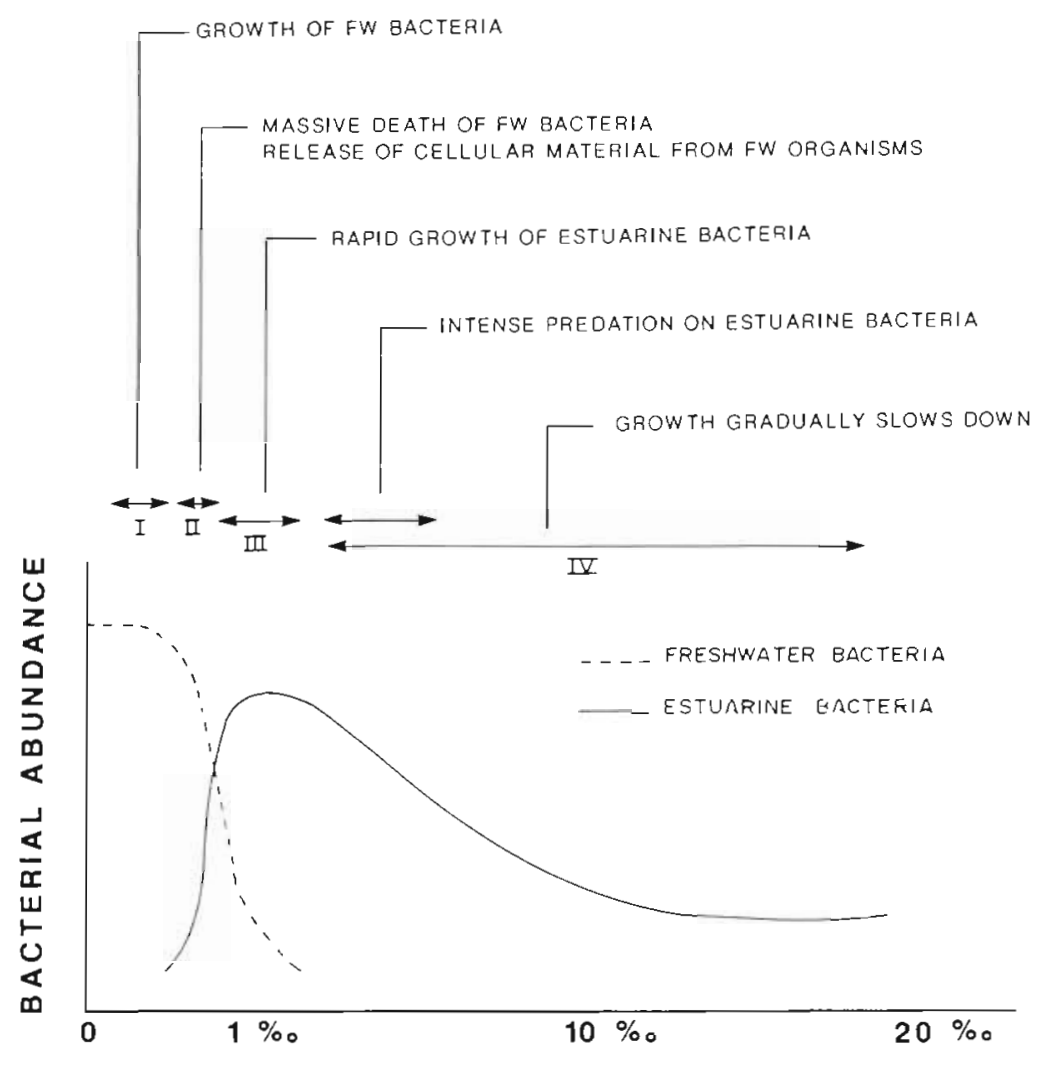

SALINITY
Fig. 6. Conceptual model of the dynamics of bacteria in estuaries 
dynamics in estuaries. In particular, the apparent contradiction between the massive mortality of freshwater bacteria and the high growth rates of estuarine bacteria has been interpreted. To gain better insight into the processes controlling bacterial abundance, a relevant quantitative study can now be undertaken, particularly in the section of the St. Lawrence Estuary below the limit of salt intrusion. More precise measurements of biological processes (growth, mortality and predation) and of water mass exchange are needed to determine the relative importance of the various processes outlined in the present conceptual model.

Acknowledgements. This study was initiated as an unsolicited proposal (contract FP7 15-2-00814) when J. P. was with the firm Bio-Conseil Inc., where M. Gagnon was of great administrative and scientific help. D. Dubois efficiently carried out lab work and bacterial counts. We thank A. Bah and M. Levasseur for helpful discussions. L. J. Albright lent the diffusion chambers and discussed various aspects of this work and J. A. Fuhrman gave us useful advice on the thymidine uptake methodology.

\section{LITERATURE CITED}

Albright, L. J. (1983a). Influence of river-ocean plumes upon bacterioplankton production of the Strait of Georgia, British Columbia. Mar. Ecol. Prog. Ser. 12: 107-113

Albright, L. J. (1983b). Heterotrophic bacterial biomasses, activities, and productivities within the Fraser River plume. Can. J. Fish. Aquat. Sci. 40 (Suppl. 1): 216-220

Anderson, G. F. (1986). Silica, diatoms and a productivity maximum in Atlantic coastal plain estuaries, Chesapeake Bay. Estuar. coast. Shelf Sci. 22: 183-198

Andersen, P., Fenchel, T (1985). Bacterivory by microheterotrophic flagellates in seawater samples. Limnol. Oceanogr 30: 198-202

Azam, F., Fenchel, T., Field, J. E., Gray, J. S., Meyer-Reil, L. A., Thingstad, F. (1983). The ecological role of water column microbes in the sea. Mar. Ecol. Prog. Ser. 10: 257-263

Bell, C. R., Albright, L. J. (1981). Attached and free-floating bacteria in the Fraser River estuary. British Columbia, Canada. Mar. Ecol. Prog. Ser 6: 317-327

Bird, D. F., Kalff, J. (1984). Empirical relationships between bacterial abundance and chlorophyll concentration in fresh and marine waters. Can. J. Fish. Aquat. Sci. 41: 1015-1023

Bousfield, E. L., Filteau, G., O'Neill, M. Gentes, P. (1975). Population dynamics of zooplankton in the middle St. Lawrence Estuary. In: Cronin, L. E. (ed.) Estuarine Research, Vol. I. Academic Press, New York, p. 325-351

Christian, R. R., Stanley, D. W., Daniel, D. A. (1984). Microbiological changes occurring at the freshwater-seawater interface of the Neuse River Estuary, North Carolina. In: Kennedy, V S. (ed.) The estuary as a filter Academic Press, Orlando, p. 349-365

Davis, P. G., Sieburth, J. McN. (1984). Estuarine and oceanic microflagellate predation of actively growing bacteria: estimation by frequency of dividing bacteria. Mar Ecol. Prog. Ser. 19: 237-246
Ducklow, H. W (1982). Chesapeake Bay nutrient and plankton dynamics. I. Bacterial biomass and production during spring tidal destratification in the York River, Virginia, estuary. Limnol. Oceanogr. 27: 651-659

Ducklow, H. W., Kirchman, D. L. (1983). Bacterial dynamics and distribution during a spring diatom bloom in the Hudson River Plume, USA. J. Plankton Res. 5: 333-356

El-Sabh, M. I. (1979). The Lower St. Lawrence Estuary as a physical oceanographic system. Naturaliste can. 106: 55-73

Erkenbrecher, C. W. (1982). The seasonal distribution of aerobic, heterotrophic bacteria in an urban Chesapeake Bay estuary. Virginia J. Sci. 33: 3-12

Fenchel, T (1982). Ecology of heterotrophic microflagellates. IV Quantitative occurrence and importance as bacterial consumers. Mar. Ecol. Prog Ser. 9: 35-42

Filardo, M. J., Dunstan, W. M. (1985). Hydrodynamic control of phytoplankton in low salinity waters of the James River estuary, Virginia, USA. Estuar coast. Shelf Sci. 21: $653-667$

Fischer, H. B., List, E. J., Koh, R. C. Y., Imberger, J., Brooks, N. H. (1979). Mixing in inland and coastal waters. Academic Press, New York

Fuhrman, J. A., Azam, F. (1980). Bacterioplankton secondary production estimates for coastal waters of British Columbia, Antarctica, and California. Appl environ. Microbiol. 39: 1085-1095

Fuhrman, J. A., Azam, F. (1982). Thymidine incorporation as a measure of heterotrophic bacterioplankton production in marine surface waters: evaluation and field results. Mar. Biol. 66: 109-120

Gordon, D. C., Cranford, P. J. C., Desplanque, C. (1985). Observations on the ecological importance of salt marshes in the Cumberland Basin, a macrotidal estuary in the Bay of Fundy. Estuar coast. Shelf Sci. 20: 205-227

Griffiths, R. P., Hayasaka, S. S., McNamara, T M., Morita, R. $Y$ (1977). Comparison between two methods of assaying relative microbial activity in marine environment. Appl. environ. Microbiol. 34: 801-805

Haas, L. W., Webb, K. L. (1979). Nutritional mode of several non-pigmented microflagellates from the York River Estuary, Virginia. J. exp. mar Biol. Ecol. 39: 125-134

Hansen, D. V., Rattray, M. (1966). New dimensions in estuary classification. Limnol. Oceanogr 11 319-326

Hobbie, J. E., Daley, R. J., Jasper, S. (1977). Use of Nuclepore filters for counting bacteria by epifluorescence microscopy. Appl. environ. Microbiol. 33: 1225-1228

Joint, I. R., Pomroy, A. J. (1982). Aspects of microbial heterotrophic production in a highly turbid estuary. J. exp. mar Biol. Ecol. 58: 33-46

Ketchum, B. H. (1954). Relation between circulation and planktonic populations in estuaries. Ecology 35: 191-200

Ketchum, B. H., Ayers, J. C., Vaccaro, R. F. (1952). Processes contributing to the decrease of coliform bacteria in a tidal estuary. Ecology 33: 247-258

Lackey, J. B. (1967). The microbiota of estuaries and their roles. In: Lauff, G. H. (ed.) Estuaries. A.A.A.S. No. 83, p. 291-301, University of Georgia, USA

Laval, M. (1971). Ultrastructure et mode de nutrition du choanoflagellé Salpingeoca. Comparaison avec les choanocytes des Spongiaires. Protistologica VII (3): 325-337

Meric, P. (1975). Circulation résiduelle dans l'estuaire moyen du Saint-Laurent et son influence sur les processus sédimentaires. Centreau, rapport no. CRE-75/03, Université Laval, Québec

Morris, A. W., Mantoura, R. F. C., Bale, A. J., Howland, J. M. (1978). Very low salinity regions of estuaries: important 
sites for chemical and biological reactions. Nature, Lond. 274: $678-680$

Neu. H. J. A. (1970). A study on mixing and circulation in the St. Lawrence Estuary up to 1964. Atlantic oceanogr. Lab., Bedford Inst. Oceanogr, Dartmouth, Nova Scotia, AOL Rep. $1970-9$

Officer, C. B. (1980). Box models revisited, In: Hamilton, P., Macdonald, K. B. (ed.) Estuarine and wetland processes with emphasis on modelling. Plenum Press, New York, p. $65-114$

Painchaud, J., Therriault, J.-C. (1985). Heterotrophic potential in the St. Lawrence Estuary: distribution and controlling factors. Naturaliste can. 112: 65-76

Palumbo, A. V., Ferguson, R. L. (1978). Distribution of suspended bacteria in the Newport River estuary, North Carolina. Estuar. coast. mar. Sci. 7: 521-529

Palumbo, A. V., Ferguson, R. L., Rublee, P. A. (1984). Size of suspended bacterial cells and association of heterotrophic activity with size fractions of particles in estuarine and coastal waters. Appl environ. Microbiol. 48: 157-164.

Pocklington, R., Tan, F. (1983). Organic carbon transport in the St. Lawrence River In: Degens, E. T., Kempe, S., Soliman, H. (ed.) Transport of carbon and minerals in major world rivers, Part 2. Mitt. Geol.-Paläont. Inst. Univ. Hamburg, SCOPE/UNEP Sonderband Heft 55: p. 243-251

Prieur, D., Trousselier, M., Romana, A., Chamroux, S., Mevel, G., Baleux, B. (1984). Evolution des peuplements bactériens selon un gradient de salinité en zone estuarienne. Oceanis 10: 329-345

Pritchard, D. W. (1969). Dispersion and flushing of pollutants in estuaries. Proc. Am. Soc. Civil Eng. 95. HY1: 115-124.

Rassoulzadegan, F., Sheldon, R. W (1986). Predator-prey interactions of nanozooplankton and bacteria in an oligotrophic marine environment. Limnol. Oceanogr. 31: $1010-1021$

Rheinheimer, G. (1979). Estuarine bacterial populations and their role in the decomposition of organic material. In:
River inputs to ocean systems. Proc. Review Workshop FAO, Rome, 26-30 Mar 1979. UNESCO, IOC, UNEP, p. 283-295

Sherr, E. B., Sherr, B. F., Fallon, R. D., Newell, S. Y (1986) Small aloricate ciliates as a major component of the marine heterotrophic nanoplankton. Limnol. Oceanogr. 31 $177-183$

Valdés, M., Albright, L. J. (1981). Survival and heterotrophic activities of Fraser River and Strait of Georgia bacterioplankton within the Fraser River plume. Mar. Biol. 64: 231-241

Watanabe, K. (1980). Distribution of aerobic, heterotrophic bacteria in the Cananéia Estuary, Brazil. Acta Veterinaria (Beograd) 30: 253-275

Wilson, C. A., Stevenson, L. H., Chrzanowski, T H. (1981) The contribution of bacteria to the total adenosine triphosphate extracted from the microbiota in the water of a salt. marsh creek. J. exp. mar. Biol. Ecol. 50: 183-195

Wright, R. T (1978). Measurement and significance of specific activity in the heterotrophic bacteria of natural waters. Appl. environ. Microbiol. 36: 297-305

Wright, R. T., Hobbie, J. E. (1966). Use of glucose and acetate by bacteria and algae in aquatic ecosystems. Ecology 47 : $447-464$

Wright, R. T., Coffin, R. B. (1983). Planktonic bacteria in estuaries and coastal waters of northern Massachusetts: spatial and temporal distribution. Mar. Ecol. Prog. Ser. 11 205-216

Wright, R. T., Coffin, R. B. (1984), Measuring microzooplankton grazing on planktonic marine bacteria by its impact on bacterial production. Microb. Ecol. 10: 137-149

Zimmermann, R. (1977). Estimation. of bacterial number and biomass by epifluorescence microscopy and scanning electron microscopy. In: Rheinheimer, G. (ed.) Microbial ecology of a brackish water environment. Springer-Verlag, Berlin, p. 103-120 